\title{
DECISION-MAKING IN THE INTERNATIONAL MONETARY FUND: IMPLICATIONS FOR SOVEREIGN EQUALITY OF STATES
}

\author{
Alex Ansong * \\ Ghana Institute of Management and Public Administration, e-mail: aansong@gimpa.edu.gh
}

(Received: March 2019; Accepted: May 2019; Published: June 2019)

\begin{abstract}
The International Monetary Fund (IMF) is one of the post-Second World War international organizations set up to promote good international economic cooperation among states. Unlike international organizations like the United Nations (UN) and the World Trade Organization (which succeeded the General Agreement on Tariff and Trade 1947), decision-making in the IMF is quite peculiar in that it is based on the joint stock company model where the value of shares determine the value of a member's vote. Thus the principle of sovereign equality of states that underpins the one-member-one-vote system in the UN and WTO is absent in the IMF. This paper discusses the various decisionmaking organs in the IMF and concludes with a discussion on the sovereignty implications of the use of IMF conditionalities in the giving of loans, especially to developing countries.
\end{abstract}

Keywords: IMF decision-making, sovereign equality, conditionalities.

\section{Introduction}

The IMF, like the UN and the GATT/WTO systems, has its founding roots in World War II and the need to promote international cooperation among states [1]. The effect of the Great Depression of the 1930s on the breakdown of international economic relations and its possible contribution to the outbreak of World War II is a well-documented occurrence in world history [2]. The need to build international multilateral institutions to instil global economic stability to avert a recurrence of the Great Depression was one of the main objectives that culminated in the founding of the so called Bretton Woods Institutions - the International Monetary Fund and the International Bank for Reconstruction and Development (more popularly known as the World Bank) [3]. The IMF and its sister organisation, the World Bank, were the products of the Bretton Woods Conference held in July 1944, at Bretton Woods, New Hampshire, in the USA [4].

\footnotetext{
* Corresponding author: Alex Ansong. E-mail: aansong@gimpa.edu.gh use, distribution, and reproduction in any medium, provided the original author and source are credited.
}

44 S sciendo Journal of Legal Studies Volume 23 Issue 37/2019 ISSN 2457-9017; Online ISSN 2392-7054. 
Ansong, A., (2019)

Decision-making in the international monetary fund: implications for sovereign equality of states

The Articles of Agreement of the IMF provide that its objectives are to promote international monetary cooperation, facilitate the expansion and growth of international trade, promote exchange rate stability, the establishment of a multilateral system of payments for transactions, and to act as a lender in situations where members need emergency funds to correct balance of payment maladjustments [5]. Like the UN, the objectives of the IMF were not novel. Prior to the founding of the IMF, an international system of exchange rates based on the gold standard had been in operation from 1876 to 1914 [6]. There were efforts to restore this system after World War I but these efforts did not yield a positive result [7]. The World Economic and Monetary Conference convened in London in July $1933 \mathrm{had}$, for instance, failed to reach agreement on the suitable exchange rate for the dollar [8]. The Great Depression had also been exacerbated by 'a race to the bottom' in currency devaluations with countries adopting high barriers to trade and restrictive exchange rate practices. [9]. This resulted in the building of monetary blocs around the dominant economic powers - the UK, US and France [10]. The 'sterling bloc' formed around the UK, the 'dollar bloc' around the USA and the 'gold bloc' around France [11]. In 1936 however, the US, UK and France agreed on a common system to ensure some stability in exchange rates. This became known as the Tripartite Declaration [12].

The Bretton Woods Conference was thus a culmination of past efforts, which though had failed, provided grievous lessons on the importance of global economic stability in ensuring international peace and security [13]. The lessons from the past failed efforts served as a springboard to launch new multilateral institutions to fill in the international institutional void in the management of international economic relations. Of note is the leading role that the US and the UK played in the founding of the IMF through the works of their leading representatives, Harry Dexter White, from the US Treasury Department, and John Maynard Keynes, from the UK Treasury [14]. Thus, like the Atlantic Charter that saw the US and UK charting a pioneering role in sowing the seeds for the founding of the UN, the same can be said of the role these two states played in the founding of the IMF and its sister organisations - the World Bank and later the GATT 1947 [15]. . It is apt to say that their leading roles in the founding of these multilateral institutions after World War II was commensurate with their roles as Great Powers whose involvement and leadership in the founding of multilateral institutions was deemed crucial to the success of these institutions [16].

Richard Gardner thus observes that:

"... the Bretton Woods Conference and the crucial negotiations that preceded it were very much an Anglo-American affair, with Canada playing a useful mediating role. For historical reasons that were unique, these three countries had an unusually large influence in the negotiations. Germany, Italy, and Japan, countries 
Ansong, A., (2019)

Decision-making in the international monetary fund: implications for sovereign equality of states

that today hold a large measure of economic power, were then enemy countries and thus not represented at Bretton Woods. France was still under German occupation; its government-in-exile played only a marginal role. The lessdeveloped countries played nothing like the part they play today in international economic conferences. The Soviet Union came only at the last minute and sat on the sidelines" [17].

It is important to note that the same rationale that inspired the work on the founding of the UN to commence before the end of World War II also underpinned the founding of the Bretton Woods Institutions. It was thought that galvanising the international political will to address the economic and other problems that played contributing roles in the outbreak of World War II would be difficult once the war had ended and countries turned their attention to domestic reconstruction [18]. Consequently, the dominant Allied states in wartime automatically played varying degrees of dominance in the multilateral institutions created within that time frame [19].

\section{Membership of the IMF}

From an initial 40, membership of the IMF has grown to 189 [20]. Any state that has autonomy over its own foreign policy can be a member of the IMF [21]. A prospective member must also accede to the Articles of Agreement of the IMF to become a member as this details the rights and responsibilities of membership. On accession to the IMF, a new member is supposed to pay a quota subscription. The quota subscription is money paid to the Fund which determines a member's voting rights and the amount a member can borrow or receive from the IMF on a periodic basis. This is known as the special drawing rights [22]. Member countries that contribute more in terms of their quota subscriptions are also entitled to borrow more under the special drawing rights [23]. In this sense, the IMF is akin to a credit union. The quota subscriptions constitute the primary source of the IMF's financial resources which it in turn lends to member states in times of difficulty [24].

The amount to be paid by each member as quota subscription is not voluntarily determined by the member based on how much money it wants to contribute to the Fund. The quota subscription of each member is broadly determined based on the member's economic size [25].

Hence members with relatively bigger economies and with higher economic performances are allocated bigger quota subscriptions which also determine the percentage weight of their votes. The quota subscriptions are not static as they are subjected to five yearly reviews and can either be adjusted upward or downward based on a member's current economic size [26]. 
Ansong, A., (2019)

Decision-making in the international monetary fund: implications for sovereign equality of states

\section{Structure and Organisation of the IMF}

Article XII of the Articles of Agreement of the IMF makes provisions for the organisational structure and management of the Fund. It establishes "a Board of Governors, an Executive Board, a Managing Director, and a staff" [27]. The IMF operates an organisational model that is quite different from other international organisations like the WTO and the UN though it is also a multilateral organisation built on the same paradigm of international cooperation among states. The institutional structure of the IMF draws inspiration from the joint-stock company model where a person's vote is commensurate with the percentage value of the shares owned [28].

\subsection{The Board of Governors}

The Board of Governors sits at the apex of the IMF organisational structure and is vested with powers directly accorded to it by the Articles of Agreement, but is also empowered with competence in respect of all powers not directly conferred on it or on the Executive Board by the Agreement [29].

This position of the Board of Governors translates into decision-making as it is the highest decision-making body of the IMF and the final arbiter when it comes to the interpretation of the Articles of Agreement of the Fund [30]. The Articles of Agreement provides for different levels of majority votes in the decision-making process. The predominant majorities required for decision-making in the IMF are the 85 percent majority, 70 percent majority, and the simple majority. For example an 85 percent majority is needed for a decision to change quotas [31] while a 70 percent majority is needed for decisions regarding how a member is to pay its quota subscription after an upward review [32]. In situations where the Articles of Agreement has not specifically determined the type of majority weighted votes required to carry through a decision, all decisions of the Board of Governors are to be made by a majority of the weighted votes cast [33].

In spite of the provisions regarding voting requirements in its Articles of Incorporation, the By-Laws of the IMF make room for consensus. It provides that: "At any meeting the Chairman may ascertain the sense of the meeting in lieu of a formal vote but he shall require a formal vote upon the request of any Governor" [34]. The practice of consensus is given a more detailed analysis in the subsection on the Executive Board.

The Board of Governors represents the member states that have acceded to the IMF's Articles of Agreement and are selected based on the determinations of the members [35]. In effect, the Articles of Agreement does not prescribe how members select their representatives who serve on the Board. In most cases however, the Governors representing the respective members of the IMF are ministers of finance, governors of the central bank or a senior government official of similar status [36]. The Board of Governors consists of one Principal Governor 
Ansong, A., (2019)

Decision-making in the international monetary fund: implications for sovereign equality of states

representing a member and an Alternate Governor [37]. The substantive or Principal Governors are entitled to vote while an Alternate Governor can only vote in the absence of his/her Principal Governor [38].

As the IMF organisational structure draws inspiration from that of a private company with shareholders, the annual meeting of the Board of Governors could be said to be akin to the annual general meeting of shareholders of a company. Pursuant to Article XII:2(d) of the Articles of Agreement of the IMF, a majority of Governors constituting, at least, two-thirds of the total voting power of the Fund form a quorum in any meeting of the Board of Governors. Article XII makes provision for a system where, on a specific question, votes can be cast by Governors without the Executive Board requesting the Board of Governors to meet [39]. Decisions like remuneration, benefits and election of Executive Directors can be made based on votes cast via mail [40].

Article XII:2(b) provides that: "The Board of Governors may delegate to the Executive Board authority to exercise any powers of the Board of Governors, except the powers conferred directly by this Agreement on the Board of Governors." The powers delegated to the Executive Board thus falls within the domain of powers not directly or explicitly conferred on the Board of Governors by the Articles of Agreement. The directly conferred powers that cannot be delegated include those relating to approval of increases in members' quotas, special drawing right allocations, approval of accession of new members, decisions on compulsory withdrawal of members and amendments of the Funds' Articles of Agreement and By-Laws [41]. The Board of Governors also exercises the responsibility of electing or appointing the Executive Directors [42].

There are two committees - the International Monetary and Financial Committee (IMFC) and the Development Committee - that are constituted by Governors drawn from the 189 Board of Governors. Pursuant to Article XII:2(j), the Board of Governors of the Fund is empowered to create advisory committees.

The IMFC came into being in 1999 by a Resolution of the Board of Governors to succeed the Interim Committee. It was established to be a permanent committee and it mirrors the constitution of the Executive Board in terms of country distribution and number [43]. The IMFC is thus made up of 24 Governors from member states and it "deals with unfolding events that may disrupt the global monetary and financial system" [44]. It is vested with monitoring and advisory roles. Its monitoring roles include scrutiny of global liquidity and resource transfer to developing countries while its advisory role relates to the provision of advice to the Board of Governors [45]. Proposals from the Executive Board with regards to amendment of the Articles of Agreement are considered by the IMFC [46] and it is also tasked with the responsibility of receiving and discussing reports from the Executive Board and the Managing Director on matters of critical importance to

48 sciendo Journal of Legal Studies Volume 23 Issue 37/2019 ISSN 2457-9017; Online ISSN 2392-7054.

Web: publicatii.uvvg.ro/index.php/jls. Pages $44-66$ 
Ansong, A., (2019)

Decision-making in the international monetary fund: implications for sovereign equality of states

the global economy and the Fund [47]. Thus the general work of the IMFC feeds into its advisory service to the Board of Governors. Due to its status as an advisory body, the IMFC does not wield decision-making powers. It meets on a biannual basis normally during the spring and just before the annual meeting of the Board of Governors in September-October [48]. Despite its status as an advisory body, Alexander Mountford has observed that the IMFC is very influential [49]. He states that:

"The IMFC has in practice become the main source of ministerial-level advice, guidance, and feedback to the Executive Board on all the main issues facing the Fund. Although it is formally an advisory committee, in practice its communiqué plays an important role in the establishing of the Fund's work program for the period ahead. The IMFC has discussed, influenced, and endorsed every major initiative (...). In practice, its advisory role has evolved in such a way that it is the IMFC that, at the highest political level, has provided ministerial-level endorsement of the decisions taken by the Executive Board" [50].

The important advisory role of the IMFC is crucial in the analysis of decisionmaking in the IMF. The only body in the IMF where all members are directly represented is the Board of Governors. In spite of the value of a member's weighted vote, there is an opportunity to use it directly at the level of the Board of Governors. The restricted membership of the IMFC and its significance in the Funds decision-making process means that even at the level of the Board of Governors, there could be a double diminution of the influence of weaker states firstly, their weakness is made apparent by the weighted voting system where the value of a member's vote is determined by its quota subscription and; secondly the restricted membership of the IMFC which, though an advisory committee, wields a lot of influence in the decision-making process.

The Development Committee on the other hand is constituted of 25 Governors drawn from the Boards of Governors of the IMF and World Bank [51]. The 'Development Committee' is the short name for the Joint Ministerial Committee of the Boards of Governors of the Bank and Fund on the Transfer of Real Resources to Developing Countries. The main rationale for its establishment is to advice the IMF and World Bank's Boards of Governors on key development issues in developing countries and the needed financial resources required to spur their economic development [52]. Like the IMFC, the Development Committee meets on a biannual basis.

It is worthy of note that though the (current) membership of both the IMFC and the Development Committee is drawn from a broad spectrum of states from developing countries, transition economies and developed countries, the members of the G-8 - the USA, UK, Russia, Japan, Italy, Germany, France, and Canada are represented in these two committees [53]. 
Ansong, A., (2019)

Decision-making in the international monetary fund: implications for sovereign equality of states

\subsection{The Executive Board}

The Executive Board is below the Board of Governors in the IMF's organisational hierarchy. It operates on the basis of powers directly accorded to it by the Articles of Agreement and powers delegated to it by the Board of Governors [54]. Section 15 of the By-Laws of the IMF provides that:

"The Executive Board is authorized by the Board of Governors to exercise all the powers of the Board of Governors except those conferred directly by the Articles of Agreement on the Board of Governors."

The breadth of this delegation of powers to the Executive Board is really wide as it is the Executive Board that is "responsible for conducting the business of the Fund, and for this purpose shall exercise all the powers delegated to it by the Board of Governors" [55]. Also, this means that where the Articles of Agreement empowers the Fund to act in any area, that power automatically falls within the remit of the Executive Board. This is because pursuant to Article XII:2(a), all powers not directly accorded to any of the IMF organs by the Articles of Agreement are vested in the Board of Governors. It is, therefore, this Article XII:2(a) competence of the Board of Governors that has been delegated to the Executive Board [56]. The Executive Board thus makes the decisions that would have been made by the Board of Governors under Article XII:2(a).

The Executive Board consists of 24 Executive Directors, five of whom are appointed by the five members with the largest quotas (i.e. the US, Japan, Germany, France and the UK) with the remaining 19 elected to represent the remaining 182 members [57]. At the inception of the IMF, the Executive Board had 12 Executive Directors, but increase in size of membership over time has necessitated the increase in the number of the Directors [58]. Though the Articles of Agreement of the Fund does not formally accord the right to any other members (apart from the ones with the five largest individual quotas) to directly appoint an Executive Director to the Board, the current reviewed quotas allow China, Saudi Arabia and Russia (with Syria) to appoint their own Directors [59]. Consequently, eight of the 189 members of the Fund directly appoint their own Executive Directors to the Executive Board leaving 179 members to elect the remaining 16 Executive Directors.

The members who do not exercise a right to appoint their own Executive Directors congregate into constituencies to elect a Director to the Executive Board. These constituencies vary in size. For instance Bangladesh, Bhutan, India, and Sri Lanka form one constituency while the two constituencies with the largest number of members - i.e. 22 [60] and 21 [61] members respectively - represent most of the African country members of the IMF [62]. It is worthy of note that the constituency with the largest number of members, representing 22 African countries, has the lowest weighted vote of 1.55 percent [63]. Thus, electing a Director to the

50 sciendo Journal of Legal Studies Volume 23 Issue 37/2019 ISSN 2457-9017; Online ISSN 2392-7054.

Web: publicatii.uvvg.ro/index.php/jls. Pages $44-66$ 
Ansong, A., (2019)

Decision-making in the international monetary fund: implications for sovereign equality of states

Executive Board through the constituency system does not translate into actual influence in decision-making. Algeria, Ghana, Morocco and Tunisia (grouped with Afghanistan, Iran, and Pakistan) are among the very few African countries represented in less crowded constituencies. Increasing developing countries' representation and influence at the Executive Board are among some of the central proposals made regarding reform of decision-making and governance in the IMF [64].

The various constituencies elect a Director to serve for a two-year period and at the expiry of this term, a new Director is elected (or the same Director is re-elected) to represent the members of the constituency [65]. In spite of the inability of most IMF members to appoint their own Directors to the Executive Board, Article XII:3(j) makes room for members without direct representation on the Board to send a representative to any meeting of the Board in situations where an issue under consideration particularly affects the member. This provision also allows attendance of Executive Board meetings by a member's representative if the Board is considering a matter that arose as a result of a request made by the member [66]. Section 19 of the By-Laws of the IMF further elaborates on the representation of members who are not eligible to appoint their own Executive Directors. Pursuant to Section 19:1(a) of the By-Laws, the Executive Board is vested with the power to determine whether a matter under consideration particularly affects a member and this determination is final. However, a member need not request to attend a Board meeting before the process of determining its qualification to attend the meeting is effected [67]. The Executive Board can, on its own initiative, make a determination that a matter under consideration in a meeting particularly affects a member and thus invite the member in question to attend the said meeting (or meetings) [68]. It is however not mandatory for a member to request to attend a meeting even if the matter under consideration particularly affects it and neither is a member obliged to attend Executive Board meetings when invited [69].

A fundamental feature of the Executive Directors of the Board that distinguishes the IMF from other international organisations like the WTO and UN is that the Articles of Agreement are silent about the status of the Directors as representatives of the members appointing or electing them. Thus unlike the WTO where members appoint their officials to represent their positions in the decision-making organs, the formal legal situation of the IMF is different. In this regard Francois Gianviti observes that:

"There are ... a number of other reasons for concluding that the Executive Directors are not representatives of their constituents, regardless of whether they are elected or appointed. For instance, in contrast with the UN charter and those of other organizations, the IMF's Articles never use the term "representatives" when referring to Governors or Executive Directors. (...) In this respect, it may be 
Ansong, A., (2019)

Decision-making in the international monetary fund: implications for sovereign equality of states

noted that the UN Convention makes a distinction between "representatives of members at meetings convened by a specialized agency" ... and "officials" of a specialized agency ... For purposes of the Convention, the UN Secretariat has been informed that Executive Directors of the IMF are not "representatives of members" but "officials of the Fund" [70].

The assertion that Executive Directors (and Governors) are not representatives of members appointing or electing them should be seen as a formal position. It would be difficult to conceptualise a situation where, especially, Executive Directors appointed by the eight countries that exercise the right of appointment would expressly go against the wishes of their appointers. This is even more the case considering the fact that votes in the Executive Board are not equal but are rather based on the weighted votes of the appointing member or electing constituency. Again, if Executive Directors are not expected to represent their appointers or constituencies, it would be difficult to reconcile the fact that members who do not have a right to appoint an Executive Director are given the opportunity of 'temporary' representation if the Board is deciding an issue that particularly affects them, while this same opportunity is not granted to members that directly appoint Directors to the Board [71]. Obviously, this would be due to the fact that an appointed Director would represent the positions of its appointer in deliberations of the Board that affect his/her appointer's interest.

Richard Swedberg, for instance, observes that the Executive Director appointed by the US is "ordered by law to clear his or her decisions with the Secretary of the Treasury" [72]. Evidently, the idea that Executive Directors do not represent their appointers or electors cannot be sustained by the facts. Also, considering the fact that the aims and objectives of the IMF, as provided in the Articles of Agreement, are all economic in nature, one would expect that these economic objectives would constitute the central ethos of IMF decision-making [73]. Influence from the leading economies are however brought to bear on the decision-making process and the Executive Board becomes prone to making decisions based not on economic considerations alone but also on the political influences of the great economic powers of the IMF [74].

David Finch argues that if economic considerations formed the sole basis of Executive Board decisions, it would not be able to explain why the Fund continues to lend to certain countries that exhibit low levels of compliance with IMF conditionalities [75]. The conditionalities themselves are supposed to be based on economic considerations as they are thought to restructure economies in crisis [76]. Non-compliance would thus mean that the rationale for lending has been breached and as such subsequent lending would not have been forthcoming. Consequently, continuous lending in such circumstances may denote non-economic influences outside the Executive Board itself, and the countries with the clout to exert this

52 sciendo Journal of Legal Studies Volume 23 Issue 37/2019 ISSN 2457-9017; Online ISSN 2392-7054.

Web: publicatii.uvvg.ro/index.php/jls. Pages $44-66$ 
Ansong, A., (2019)

Decision-making in the international monetary fund: implications for sovereign equality of states

influence are the leading economies in the IMF [77]. This lends further credence to the notion that Executive Directors are not dispassionate technocrats who are insulated from the controls of their appointers and electors.

Morten Boas and Desmond McNeill also argue that:

"Formally, the IMF is not granted very much autonomy. The chain of command is supposed to run directly from governments of member countries to the IMF. Thus, when the IMF works out lending arrangements, including conditionalities, the IMF formally acts not on its own, but as an intermediary between the will of the majority of the membership and the individual member country. However, it is very clear that those who contribute the most to IMF ... are also given the strongest voice in determining policies. This means that the IMF, if it is an intermediary, is an intermediary between the strongest economies in the world and individual member countries, and not necessarily between the majority and the individual" [78].

It must be noted though that in spite of the varying weights of vote reflected in the composition of the Executive Board, the norm in decision-making is consensus. The practice of consensus does not however preclude a resort to voting as any Executive Director can request a formal vote to be taken [79]. Pursuant to Rule C10 of the Rules and Regulations of the IMF, the Chairman of the Executive Board [80] is tasked with the responsibility of ascertaining "the sense of the meeting in lieu of a formal vote [81]. Judging 'the sense of the meeting' of the Executive Board is an ascertainment of the consensus of the meeting [82]. The practice of consensus may help shore up the role of weaker states in Executive Board decision-making as it is apparent that a resort to formal voting would entrench their marginalized position due to the weighted vote system.

However, achieving consensus would not mean that all the Executive Directors exercise equal leverage [83] as is formally the case in the WTO decision-making organs, for example. In the WTO, votes are not weighted so, in principle, every member's consent is required for consensus to work. Consequently, to talk about consensus decision-making in a body with weighted votes would be an exaggeration or over simplification of the reality. Consensus may be 'exacted' by those with the largest votes as the rest of the membership (represented through their Executive Directors) would know all too well that if the matter is subjected to a vote, they would lose. For example, in the decisions that require 85 per cent majority [84] to pass, the US with 16.5 per cent of the weighted votes [85] singlehandedly wields a veto. Knowledge that a proposed policy would be objected to by the USA, would require amendment or bargaining in order to bring the US on board. In decisions that require 70 per cent majority [86], the five countries with the largest weighted votes exercise a default veto if they act together as their combined votes account for 36 per cent of the total weighted votes [87]. Reflecting 
Ansong, A., (2019)

Decision-making in the international monetary fund: implications for sovereign equality of states

on the US's decision-making powers in the Executive Board, Peter Kenen observes that:

"It is fairly safe to say that the U.S. voting share will never fall below 15 percent of the total voting power in the IMF without the consent of the United States. Such a change would deprive the United States of its ability to block decisions requiring an 85 percent majority, including decisions to change Fund quotas and to amend the Fund's Articles of Agreement. It is, in fact, nearly impossible to strip the United States of that blocking power, because the same 85 percent majority is needed to approve an increase or redistribution of IMF quotas.

It should also be noted that U.S. participation in the Fund is governed by the Bretton Woods Agreement Act, not by a treaty, and that U.S. quota increases are treated as appropriations, although they are not treated as budgetary outlays because they represent an exchange of assets between the United States and the Fund. Therefore, both the Senate and the House of Representatives must approve all decisions involving increased U.S. participation in the Fund, and they would be sure to reject any change in the distribution of IMF quotas that deprived the United States of its ability to block those critical decisions" [88].

Thus, consensus in the IMF may be more accurately described as agreement based on the tacit acceptance of the superior leverage of the great economic powers. Leo van Houtven also observes that:

"The Board works as a college of officials who devote themselves full time to the tasks and purposes of the IMF. The "sense of the meeting," which the chairman must ascertain, is a position that is supported by Executive Directors having sufficient votes to carry the question if a vote were taken. "Consensus" denotes unanimity. While unanimity remains the objective, the Chairman and the Board view the achievement of "a large majority" as sufficient for many decisions" [89].

\subsection{The Managing Director and Staff of the IMF}

The Executive Board is chaired by the Managing Director of the IMF who, though acting as the chairman of the Board, does not possess voting powers. The inability to exercise voting powers is only waived in situations where there is an equal division in the votes cast [90]. This scenario is however virtually implausible as most Executive Board decisions are taken by majorities that exceed 50 per cent. Even where a simple majority of weighted votes is required to carry through a decision of the Board [91], getting a 50-50 divide of votes remains unlikely.

The managing Director is appointed by the Executive Board and his/her tenure can also be terminated by the Board [92]. Article XII:4(b) provides that:

"The Managing Director shall be chief of the operating staff of the Fund and shall conduct, under the direction of the Executive Board, the ordinary business of the Fund. Subject to the general control of the Executive Board, he shall be

54 sciendo Journal of Legal Studies Volume 23 Issue 37/2019 ISSN 2457-9017; Online ISSN 2392-7054.

Web: publicatii.uvvg.ro/index.php/jls. Pages $44-66$ 
responsible for the organization, appointment, and dismissal of the staff of the Fund" [93].

The Managing Director and operating staff of the IMF do not represent members and are as such required to execute their duties entirely for the purposes of the Fund and no other authority [94]. Members are therefore charged to respect the international character of the functions discharged by the operating staff and in this respect refrain from any attempts to influence them in the discharge of their duties [95].

The overriding principle in the recruitment of the operating staff of the Fund is that of "securing the highest standards of efficiency and of technical competence" [96]. Though there is mention of paying "due regard to the importance of recruiting personnel on as wide a geographical basis as possible" [97], the emphasis is on technical excellence hence making the geographical requirement a secondary one. Ngaire Woods observes that:

"Unlike other UN institutions, the Fund and Bank are situated in the capital of the US government in Washington, DC, and work exclusively in English. This, combined with the fact that they draw a large proportion of their staff from graduate programs in North America makes the Fund and Bank the most 'AngloSaxon' of the current generation of international organisations" [98].

The Managing Director is obliged to report any breaches committed by a member in respect of the obligations they have assumed to the Executive Board, under the Fund's Articles of Agreement [99]. For example, pursuant to Article XXVI:2 of the Articles of Agreement, failure by a member to fulfil its obligations under the Agreement could result in a decision refusing the member in question from using the resources of the Fund. This is referred to as a declaration of ineligibility [100]. Persistence of the breach of obligations by the offending member could result in a suspension of its voting rights [101]. A report of the Managing Director regarding a member's breach of the Articles of Agreement can therefore result in action by the Executive Board.

\section{Conclusion: IMF Decision-Making and Sovereignty Equality of Sates}

The decision-making system in the IMF raises some issues of democracy and sovereignty, especially with respect to the conditionalities attached loans given to States. The current system in the IMF where, mostly, some developed countries have become the creditors and developing countries the borrowers can provide some insight into the power dynamics in the Fund. In the IMF, policy prescriptions that have become known as the Washington Consensus feed into the conditionalities that are attached to loans [102]. John Williamson identified certain key policy areas around which consensus could be built by the important decisionmaking institutions in the US government and international financial institutions. 
Ansong, A., (2019)

Decision-making in the international monetary fund: implications for sovereign equality of states

The said policy areas are fiscal deficits, public expenditure priorities, tax reform, interest rates, the exchange rate, trade policy, foreign direct investment, privatization, deregulation, and property rights. Though IMF conditionalities have undergone reform over the years with current emphasis on country ownership of policy prescriptions [103], the 10 policy areas identified by Williamson are still relevant in IMF prescriptions. The leading Western developed countries in the IMF are noted for promoting the Washington Consensus [104]. Hence the conditionalities can be viewed as an indirect economic policy prescription from the leading creditor countries to the developing countries that are recipients of IMF credit, with the IMF serving only as the intermediary [105].

Concepts like the sovereign equality of States that form the basis of post-World War II international legal order would hardly be operable in the IMF. This is due to the joint-stock company model which is peculiar to the IMF (and the World Bank) among international organisations. Thus the use of the one-member-one-vote system which actualises the principle of sovereign equality in the UN General Assembly or the WTO's Ministerial Conference and General Council is alien to the IMF decision-making system. With the IMF therefore, the only aspect of the principle of sovereign equality that applies is the fact that members are sovereign States that have acceded to the Fund's Articles of Agreement. The sovereignty of the members as States does not translate into equality in the decision-making process. Like the joint-stock company model, individuals who are equal under the law of the land are not equal with respect to their influence over the decisions of the company in which they own shares. Those with a greater percentage of the shares have votes equivalent to the value of their shares. So also, in the IMF, sovereign equality can only be conceived of as equality of states under international law and not equality in terms of actual influence in the organisations that states join. Hans Kelsen argued that:

"The sovereignty of the States, as subjects of international law, is the legal authority of the States under the authority of international law. If sovereignty means "supreme" authority, the sovereignty of the States as subjects of international law cannot mean an absolutely, but only a relatively supreme authority; the State's legal authority is "supreme" insofar as it is not subjected to the legal authority of any other State. The State is "sovereign" since it is subjected only to international law, not to the national law of any other State. The State's sovereignty under international law is the State's legal independence from other States" [106].

The implications of Kelsen's argument, with respect to decision-making and conditionalities in the IMF, can be twofold. First, by being subjected to conditionalities in the IMF, states experience a diminution of their sovereignty, as they are subjected to the policy preferences of the creditor or benefactor states. The

56 sciendo Journal of Legal Studies Volume 23 Issue 37/2019 ISSN 2457-9017; Online ISSN 2392-7054.

Web: publicatii.uvvg.ro/index.php/jls. Pages $44-66$ 
Ansong, A., (2019)

second implication can be seen as an opposite side of the first argument - states that accept conditionalities in the IMF do so as a legitimate expression of their sovereignty. It is an expression of state consent.

The problem with the second argument is how to construe consent where there are no viable alternatives to choose from. If IMF loans are effectively indispensable to the countries that need them, then their consent to the conditionalities tied to the loans may be seen more as an exacted consent, and this would raise legitimate issues of sovereignty and equality. On the other hand it may be argued that the $\mathrm{UN}$, for example, has enshrined the principle of sovereign equality its Charter [107] and yet has principal organs like the Security Council and the Economic and Social Council that have restricted membership. There is even weighted voting in the Security Council by dint of the operation of the veto power by the five permanent members. However, in an organ like the Economic and Social Council, there is a 'rotational' system of electing new members after 'old' members have completed serving their term. Consequently, every UN member has the opportunity to serve as a member. This preserves sovereign equality by ensuring equality of possible representation. What is perceived as a problem in the UN system is the permanent membership with its attendant veto powers in the Security Council.

Though the issue of conditionalities in the IMF has engendered much criticism, it also raises some fundamental legitimate questions. For example, is it unrealistic for a bank to ensure that the loan it gives to a customer is used judiciously for the purpose for which the customer procured it? Supposing I apply for a mortgage from a bank, do I have the liberty to use the loan to purchase anything I fancy and justify my actions with the excuse that I am responsible for paying back the loan and so I should have the freedom to use it on whatever I like? Should the bank have a right to require me to take life insurance and property insurance as conditionalities for giving me the mortgage? If one considers the questions posed above, it is reasonable to see possible limitations on my freedom (sovereignty) as an individual if I should agree to the conditions set by the bank. However, it is also the price I have to pay for getting what I want from the bank. I have the choice of not taking the loan. This safeguards my freedoms. However, if I deem the loan to be of fundamental importance to my survival or development, then I should be prepared to trade some of my freedoms as conditionalities for accepting the loan from the bank. Thus, operationalising purist concepts like sovereign equality of States in an organization like the IMF presents problems of synergy between principles and actual practice or the ideal and the actual.

\section{Acknowledgements}

The authors thank the anonymous reviewers and editor for their valuable contribution. 
Ansong, A., (2019)

"Vasile Goldiş" Western University of Arad

Decision-making in the international monetary fund: implications for sovereign equality of states

\section{Funding}

This research received no specific grant from any funding agency in the public, commercial, or not - for - profit sectors.

\section{Author Contributions}

The author conceived the study, carried out the literature review agenda and was responsible for the design, data collection, legislative analysis and case interpretation.

\section{Disclosure Statement}

The authors have not any competing financial, professional, or personal interests from other parties.

\section{References}

1.Anghie, A. (2000). Time Present and Time Past: Globalization, International Financial Institutions and the Third World, New York University Journal of International Law and Politics, 32(2).

2.Argy, V., (1981). The Postwar International Monetary Crisis: An Analysis, London: George Allen \& Unwin.

3.Bernstein, E. (1996). The Making and Remaking of the Bretton Woods Institutions, in Orin Kirshner (ed.), The Bretton Woods-GATT System: Retrospect and Prospect After Fifty Years, New York: M. E. Sharpe Inc.

4.Boas, M., McNeill, D. (2003). Multilateral Institutions: A Critical Introduction, Pluto Press, London.

5.Boughton, J.M. (2003). Who's in Charge? Ownership and Conditionality in IMFSupported Programs, IMF Working Paper, WP/03/191.

6.Broad, R. (2004). The Washington Consensus Meets the Global Backlash: Shifting Debates and Policies, Globalizations, 1(2), pp. $129-154$.

7.Chimni, B.S. (2006). Third World Approaches to International Law: A Manifesto', International Community Law Review, 8, pp.3-27.

8.David M. Andrews, D.M. (2008). Bretton Woods: System and Order', in David M. Andrews (ed.), Orderly Change: International Monetary Relations since Bretton Woods, Cornell University Press, New York.

9.Emerson Hall, T., Ferguson, J.D. (1998). The Great Depression: An International Disaster of Perverse Economic Policies, University of Michigan Press, Michigan.

10. Finch, D.C. (1989). The IMF: The Record and the Prospects, Princeton Essays in International Finance, No. 175.

11. Gardner, R.N. (1972).The Political Setting, in A.L.K. Acheson, J.F. Chant, and M.F.J. Prachowny (eds.), Bretton Woods Revisited: Evaluations of the

58 sciendo Journal of Legal Studies Volume 23 Issue 37/2019 ISSN 2457-9017; Online ISSN 2392-7054.

Web: publicatii.uvvg.ro/index.php/jls. Pages $44-66$ 
Ansong, A., (2019)

Decision-making in the international monetary fund: implications for sovereign equality of states

International Monetary Fund and the International Bank for Reconstruction and Development, University of Toronto Press, Toronto.

12. Garritsen de Vries, M. (1996). The Bretton Woods Conference and the Birth of the International Monetary Fund, in Orin Kirshner (ed.), The Bretton WoodsGATT System: Retrospect and Prospect After Fifty Years, M. E. Sharpe Inc, New York, pp.3-18.

13. Gianviti, F. (1999). Decision-Making in the International Monetary Fund', in Current Developments in Monetary and Financial Law, Vol.1, Legal Department of the IMF and the IMF Institute, International Monetary Fund, Washington D.C, pp.31-67.

14. Gilpin, R. (1987). The Political Economy of International Relations, New Jersey: Princeton University Press.

15. Gore, C. (2000). The Rise and Fall of the Washington Consensus as a Paradigm for Developing Countries, World Development, 28(5), pp. 789-804.

16. Held, D. (2004). Global Covenant: The Social Demoratic Alternative to the Washington Consensus, Polity Press, Cambridge.

17. Kelsen, H. (2000). Peace Through Law, The Lawbook Exchange Ltd, New Jersey.

18. Kenen, P.B. (2007). Reform of the International Monetary Fund, New York: Council on Foreign Relations, CSR NO. 29.

19. Keohane, R. O. (1984). After Hegemony: Cooperation and Discord in the World Political Economy, Princeton University Press, New Jersey.

20. Macbean A.I., Snowden, P.N. (1981). International Institutions in Trade and Finance, George Allen \& Unwin, London.

21. Mountford, A. (2008). The Formal Governance Structure of the International Monetary Fund', Independent Evaluation Office of the International Monetary Fund, Background Paper, BP/08/01.

22. Naim, M. (2000). Washingto Consensus or Washington Confusion?, Foreign Policy, Spring, pp.87-102.

23. Peet, R. (2009). Unholy Trinity: The IMF, World Bank and WTO, Zed Books, London.

24. Portugal, M. (2005). Improving IMF Governance and Increasing the Influence of Developing Countries in IMF Decision-Making', in Ariel Buira (ed.), Reforming the Governance of the IMF and the World Bank, Anthem Press, London, pp.75-106.

25. Rodrik, D. (2001). The Global Governance of Trade: As if Development Really Mattered, United Nations Development Programme, New York.

26. Rowden, R. (2009). The Deadly Ideas of Neoliberalism: How the IMF has Undermined Public Health and the Fight Against AIDS, Zed Books, London, pp.49-78. 
Ansong, A., (2019)

Decision-making in the international monetary fund: implications for sovereign equality of states

27. Seavoy, R.E. (2003). Origins and Growth of the Global Economy: From the Fifteenth Century Onwards, Greenwood Publishing Group Inc., Westport.

28. Stevenson, J. (2000). Preventing Conflict: The Role of the Bretton Woods Institutions, The International Institute for Strategic Studies, Adelphi Papers 336, Oxford University Press, Oxford.

29. Stiglitz, J. (2002). Globalization and its Discontents, Penguin Books, London. 30. Swedberg, R. (1986). The Doctrine of Economic Neutrality of the IMF and World Bank, Journal of Peace Research, 23(4).

31. Thacker, S.C. (2006). The High Politics of IMF Lending, in Gustav Ranis, James Raymond Vreeland, and Stephen Kosack (eds.), Globalisation and the Nation State: The Impact of the IMF and the World Bank, Routledge, Abingdon, pp.111-12.

32. Treasurer's Department, (1998). Finanacial Organization and Operations of the IMF, Pamphlet Series No.45, (5th ed.), Washington DC: IMF.

33. van Houtven, L. (2002). Governance of the IMF: Decision Making, Institutional Oversight, Transparency, and Accountability, IMF Publication Services, Pamphlet Series No. 53, Washington D.C.

34. Vernon, R. (1996). The U.S. Government at Bretton Woods and After, in Orin Kirshner (ed.), The Bretton Woods-GATT System: Retrospect and Prospect After Fifty Years, M. E. Sharpe Inc. New York, pp.52-69.

35. Williams, M. (1994). International Economic Organisations and the Third World, Harvester Wheatsheaf, Hemel Hempstead.

36. Williamson J. (ed.) (1990). Latin American Adjustment: How Much Has Happened?, Peterson Institute for International Economics, Washington DC.

37. Woods, N. (2007). Bretton Woods Institutions in Thomas G. Weiss and Sam Daws (eds.), The Oxford Handbook on the United Nations, Oxford University Press, Oxford, pp.233-253.

38. Woods, N. (2006). The Globalizers: The IMF, the World Bank, and Their Borrowers, Cornell University Press, New York.

39. Woods, N., Narlikar, A. (2001). Governance and the Limits of Accountability: The WTO, the IMF, and the World Bank, International Social Science Journal, 53(170), pp.569-583.

40. ***'The IMF at a Glance, International Monetary Fund Factsheet, https://www.imf.org/en/About/Factsheets/IMF-at-a-Glance (viewed on 19 November 2018)

41. ***'How the IMF Makes Decisions, International Monetary Fund Factsheet, ttps://www.imf.org/en/About/Factsheets/Sheets/2016/07/27/15/24/How-the-IMF-

Makes-Decisions (viewed on 18 November 2018).

60 sciendo Journal of Legal Studies Volume 23 Issue 37/2019 ISSN 2457-9017; Online ISSN 2392-7054.

Web: publicatii.uvvg.ro/index.php/jls. Pages $44-66$ 
Ansong, A., (2019)

Decision-making in the international monetary fund: implications for sovereign equality of states

42. ***'A Guide to Committees, Groups and Clubs, International Monetary Fund Factsheet, https://www.imf.org/en/About/Factsheets/A-Guide-to-CommitteesGroups-and-Clubs (viewed on 20 November 2018).

43. ***'IMF Executive Directors and Voting Power, https://www.imf.org/external/np/sec/memdir/eds.aspx (viewed on 20 November 2018).

44. ***IMF Finance Department, Quota and Voting Shares Before and After Implementation of Reforms Agreed in 2008 and 2010, https://www.imf.org/external/np/sec/pr/2011/pdfs/quota_tbl.pdf (viewed on 20 November 2018).

\section{Notes}

[1] See Ronald E. Seavoy, Origins and Growth of the Global Economy: From the Fifteenth Century Onwards, Westport: Greenwood Publishing Group Inc.; A.I. Macbean and P.N. Snowden, International Institutions in Trade and Finance, London: George Allen \& Unwin, 1981. For a more conceptual analysis see Robert O. Keohane, After Hegemony: Cooperation and Discord in the World Political Economy, New Jersey: Princeton University Press, 1984.

[2] See Thomas Emerson Hall and J. David Ferguson, The Great Depression: An International Disaster of Perverse Economic Policies, Michigan: University of Michigan Press, 1998, p.2.

[3] Robert Gilpin, The Political Economy of International Relations, New Jersey: Princeton University Press, 1987; Morten Boas and Desmond McNeill, Multilateral Institutions: A Critical Introduction, London: Pluto Press, 2003; David M. Andrews, 'Bretton Woods: System and Order', in David M. Andrews (ed.), Orderly Change: International Monetary Relations since Bretton Woods, New York: Cornell University Press, 2008, pp.6-24.

[4] Morten Boas and Desmond McNeill, ibid.

[5] Article 1 of the Articles of Agreement of the IMF. See also Victor Argy, The Postwar International Monetary Crisis: An Analysis, London: George Allen \& Unwin, 1981; Marc Williams, International Economic Organisations and the Third World, Hemel Hempstead: Harvester Wheatsheaf, 1994.

[6] Margaret Garritsen de Vries, 'The Bretton Woods Conference and the Birth of the International Monetary Fund', in Orin Kirshner (ed.), The Bretton WoodsGATT System: Retrospect and Prospect After Fifty Years, New York: M. E. Sharpe Inc., 1996, pp.3-18, at 3.

[7] Ibid.

[8] Edward Bernstein, 'The Making and Remaking of the Bretton Woods Institutions', in Orin Kirshner (ed.), The Bretton Woods-GATT System: Retrospect and Prospect After Fifty Years, New York: M. E. Sharpe Inc., 1996, pp.89-98. 
Ansong, A., (2019)

[9] ibid.

[10] Robert Gilpin, op cit. fn.3.

[11] Ibid.

[12] Edward Bernstein, op cit. fn.8.

[13] See Jonathan Stevenson, Preventing Conflict: The Role of the Bretton Woods Institutions, The International Institute for Strategic Studies, Adelphi Papers 336, Oxford: Oxford University Press, 2000.

[14] Richard N. Gardner, 'The Political Setting', in A.L.K. Acheson, J.F. Chant, and M.F.J. Prachowny (eds.), Bretton Woods Revisited: Evaluations of the International Monetary Fund and the International Bank for Reconstruction and Development, Toronto: University of Toronto Press, 1972.

[15] See Raymond Vernon, 'The U.S. Government at Bretton Woods and After', in Orin Kirshner (ed.), The Bretton Woods-GATT System: Retrospect and Prospect After Fifty Years, New York: M. E. Sharpe Inc. 1996, pp.52-69.

[16] Raymond Vernon, op cit. fn.15.

[17] Richard N. Gardner, op cit. fn.14, at 20.

[18] Ibid.

[19] See Ngaire Woods, 'Bretton Woods Institutions', in Thomas G. Weiss and Sam Daws (eds.), The Oxford Handbook on the United Nations, Oxford: Oxford University Press, 2007, pp.233-253

[20] 'The IMF at a Glance', International Monetary Fund Factsheet, https://www.imf.org/en/About/Factsheets/IMF-at-a-Glance (viewed on 19 November 2018)

[21] Victor Argy, op cit. fn.5.

[22] Richard N. Gardner, op cit. fn.14.

[23] Treasurer's Department, Finanacial Organization and Operations of the IMF, Pamphlet Series No.45, (5th ed.), Washington DC: IMF, 1998.

[24] Ibid.

[25] Ibid.

[26] Ibid.

[27] Article XII:1 of the Articles of Agreement of the IMF.

[28] Morten Boas and Desmond McNeill, op cit. fn.3.

[29] Article XII:2(a) of the Articles of Agreement of the IMF.

[30] Leo van Houtven, Governance of the IMF: Decision Making, Institutional Oversight, Transparency, and Accountability, Washington D.C.: IMF Publication Services, Pamphlet Series No. 53, 2002.

[31] Article III:2(c) of the Articles of Agreement of the IMF.

[32] Article III:3(d) of the Articles of Agreement of the IMF.

[33] Section 11 of the By-Laws of the IMF.

[34] ibid.

62 sciendo Journal of Legal Studies Volume 23 Issue 37/2019 ISSN 2457-9017; Online ISSN 2392-7054.

Web: publicatii.uvvg.ro/index.php/jls. Pages $44-66$ 
[35] ibid.

[36] Alexander Mountford, 'The Formal Governance Structure of the International Monetary Fund', Independent Evaluation Office of the International Monetary Fund, Background Paper, BP/08/01, 2008.

[37] Article XII:2(a) of the Articles of Agreement of the IMF.

[38] Article XII:2(a) of the Articles of Agreement of the IMF.

[39] Article XII:2(f) of the Articles of Agreement of the IMF.

[40] Alexander Mountford, op cit. fn.36.

[41] 'How the IMF Makes Decisions', International Monetary Fund Factsheet, https://www.imf.org/en/About/Factsheets/Sheets/2016/07/27/15/24/How-the-IMF-

Makes-Decisions (viewed on 18 November 2018).

[42] ibid.

[43] Alexander Mountford, op cit. fn.36.

[44] 'A Guide to Committees, Groups and Clubs', International Monetary Fund Factsheet, https://www.imf.org/en/About/Factsheets/A-Guide-to-CommitteesGroups-and-Clubs (viewed on 20 November 2018).

[45] ibid.

[46] ibid.

[47] Alexander Mountford, op cit. fn.36.

[48] 'A Guide to Committees, Groups and Clubs' op cit. fn.44.

[49] Alexander Mountford, op cit. fn.36.

[50] ibid at 8.

[51] Leo van Houtven, op cit. fn.30.

[52] Ibid.

[53] The IMFC is constituted of Governors from the following countries: Algeria, Brazil, Cameroon, Canada, Central African Republic, China, Colombia, Czech Republic, France, Germany, Iceland, India, Indonesia, Italy, Japan , Korea, Netherlands, Nigeria, Peru, Russia, Saudi Arabia, Switzerland, United Arab Emirates, United Kingdom, United States. Source https://www.imf.org/en/About/Factsheets/A-Guide-to-Committees-Groups-andClubs (viewed on 20 November 2018).

[54] Article XII:2(b) and 3(a) of the Articles of Agreement of the IMF.

[55] Article XII:3(a) of the Articles of Agreement of the IMF.

[56] See Francois Gianviti, 'Decision-Making in the International Monetary Fund', in Current Developments in Monetary and Financial Law, Vol.1, Legal Department of the IMF and the IMF Institute, Washington D.C.: International Monetary Fund, 1999, pp.31-67.

[57] Article XII:3(b) of the Articles of Agreement of the IMF.

[58] Francois Gianviti, op cit. fn.56. 
Ansong, A., (2019)

Decision-making in the international monetary fund: implications for sovereign equality of states

[59] 'IMF $\quad$ Executive Directors and Voting Power'

https://www.imf.org/external/np/sec/memdir/eds.aspx (viewed on 20 November 2018).

[60] Benin Burkina Faso, Cameroon, Cape Verde, Central African Republic, Chad, Comoros, Democratic Republic of Congo, the Republic of Congo, Côte d'Ivoire, Djibouti, Equatorial Guinea, Gabon, Guinea-Bissau, Mali, Mauritania, Mauritius, Niger, Rwanda, São Tomé and Príncipe, Senegal, and Togo. https://www.imf.org/external/np/sec/memdir/eds.aspx (viewed on 20 November 2018).

[61] Angola, Botswana, Burundi, Eritrea, Ethiopia, The Gambia, Kenya, Lesotho, Liberia, Malawi, Mozambique, Namibia, Nigeria, Sierra Leone, South Africa, Sudan, Swaziland, Tanzania, Uganda, Zambia, Zimbabwe. https://www.imf.org/external/np/sec/memdir/eds.aspx (viewed on 20 November 2018).

[62] Ngaire Woods, op cit. fn.19; Peter B. Kenen, Reform of the International Monetary Fund, New York: Council on Foreign Relations, CSR NO. 29, (2007).

[63] http://www.imf.org/external/np/sec/memdir/eds.aspx\#1 (viewed 16 November 2018).

[64] See Murilo Portugal, 'Improving IMF Governance and Increasing the Influence of Developing Countries in IMF Decision-Making', in Ariel Buira (ed.), Reforming the Governance of the IMF and the World Bank, London: Anthem Press, 2005, pp.75-106.

[65] Article XII:3(d) of the Articles of Agreement of the IMF.

[66] Article XII:3(i) of the Articles of Agreement of the IMF.

[67] Section19:1(c) of the By-Laws of the IMF.

[68] ibid.

[69] Section19:1(a) of the By-Laws of the IMF.

[70] Francois Gianviti, op cit. fn.56, at 46.

[71] Section19 of the By-Laws of the IMF.

[72] Richard Swedberg, 'The Doctrine of Economic Neutrality of the IMF and World Bank,' Journal of Peace Research, 23(4), 1986, p.379.

[73] Strom C. Thacker, 'The High Politics of IMF Lending,' in Gustav Ranis, James Raymond Vreeland, and Stephen Kosack (eds.), Globalisation and the Nation State: The Impact of the IMF and the World Bank, Abingdon: Routledge, 2006, pp.111-12.

[74] ibid.

[75] David C. Finch, 'The IMF: The Record and the Prospects, Princeton Essays in International Finance, No. 175, 1989.

[76] ibid.

[77] ibid.

64 sciendo Journal of Legal Studies Volume 23 Issue 37/2019

ISSN 2457-9017; Online ISSN 2392-7054.

Web: publicatii.uvvg.ro/index.php/jls. Pages $44-66$ 
Ansong, A., (2019)

[78] Morten Boas and Desmond McNeill, op cit. fn.3, at 30.

[79] Rule C-10 of the Rules and Regulations of the IMF.

[80] i.e. the Managing Director of the IMF.

[81] Rule C-10 of the Rules and Regulations of the IMF.

[82] Leo van Houtven, op cit. fn.30.

[83] Ibid.

[84] An example is Article XV:2 of the Articles of Agreement of IMF which provides for 85 percent majority of weighted votes on a decision relating to variation in the valuation of quota subscription. Pursuant to Article XII:3(b)(ii) 85 percent majority of weighted votes is needed to either increase or decrease the number of elected Executive Directors.

[85] IMF Finance Department, 'Quota and Voting Shares Before and After Implementation of Reforms Agreed in 2008 and 2010,' https://www.imf.org/external/np/sec/pr/2011/pdfs/quota_tbl.pdf (viewed on 20 November 2018).

[86] For example, pursuant to Article XV:2 of the Articles of Agreement, 70 per cent majority of weighted votes is needed to determine the principle of valuing quota subscriptions.

[87] IMF Finance Department, op cit. fn.85.

[88] Peter B. Kenen, op cit. fn.62, at 10-12.

[89] Leo van Houtven, op cit. fn.30, at 23.

[90] Article XII:4(a) of the Articles of Agreement of the IMF.

[91] e.g. Art. XXVII:1.

[92] Ibid.

[93] Article XII:4(b) of the Articles of Agreement of the IMF.

[94] Article XII:4(c) of the Articles of Agreement of the IMF.

[95] ibid.

[96] Article XII:4(d) of the Articles of Agreement of the IMF.

[97] ibid.

[98] Ngaire Woods, op cit. fn.19, at 234.

[99] Francois Gianviti, op cit. fn.56.

[100] Article XXVI:2 of the Articles of Agreement of the IMF.

[101] Article XXVI:2(b) of the Articles of Agreement of the IMF.

[102] The term 'Washington Consensus' was coined by John Williamson in 'What Washington Means by Policy Reform', John Williamson (ed.), Latin American Adjustment: How Much Has Happened?, Washington DC: Peterson Institute for International Economics (1990), chap.2.; Ngaire Woods, The Globalizers: The IMF, the World Bank, and Their Borrowers, New York: Cornell University Press, (2006); Joseph Stiglitz, Globalization and its Discontents, London: Penguin Books (2002); Antony Anghie, 'Time Present and Time Past: Globalization, International 
Ansong, A., (2019)

Decision-making in the international monetary fund: implications for sovereign equality of states

Financial Institutions and the Third World', New York University Journal of International Law and Politics, 32(2), (2000), p.243, B.S. Chimni, 'Third World Approaches to International Law: A Manifesto', International Community Law Review, 8, (2006) pp.3-27; Rick Rowden, The Deadly Ideas of Neoliberalism: How the IMF has Undermined Public Health and the Fight Against AIDS, London: Zed Books (2009) see pp.49-78; Moises Naim, 'Washingto Consensus or Washington Confusion?', Foreign Policy, Spring (2000), pp.87-102; Charles Gore, 'The Rise and Fall of the Washington Consensus as a Paradigm for Developing Countries', World Development, 28(5), (2000) , pp. 789-804; Ngaire Woods and Amrita Narlikar, 'Governance and the Limits of Accountability: The WTO, the IMF, and the World Bank', International Social Science Journal, 53(170), (2001), pp.569-583.

[103] Robin Broad for instance catalogues some of the changing paradigms in the Washington Consensus brought about by both academic and global critique - see Robin Broad, 'The Washington Consensus Meets the Global Backlash: Shifting Debates and Policies', Globalizations, 1(2), (2004), pp. 129 - 154. See also James M. Boughton, 'Who's in Charge? Ownership and Conditionality in IMF-Supported Programs', IMF Working Paper, WP/03/191, (2003); Dani Rodrik, The Global Governance of Trade: As if Development Really Mattered, New York: United Nations Development Programme, (2001); David Held, Global Covenant: The Social Demoratic Alternative to the Washington Consensus, Cambridge: Polity Press, (2004); Richard Peet, Unholy Trinity: The IMF, World Bank and WTO, London: Zed Books (2009)

[104] Ngaire Woods, op cit. fn.102; Rick Rowden, op cit. fn.102; Moises Naim, op cit. fn.102, Charles Gore, op cit. fn.102.

[105] Ngaire Woods, op cit. fn.102; Rick Rowden, op cit. fn.102; Moises Naim, op cit. fn.102, Charles Gore, op cit. fn.102.

[106] Hans Kelsen, Peace Through Law, New Jersey: The Lawbook Exchange Ltd., 2000, at 35.

[107] Article 2:1 of the UN Charter, 1945. 